\title{
Potential of microalgae in the bioremediation of water with chloride content
}

\author{
M. E. Ramírez * ${ }^{a}, Y$. H. Vélez ${ }^{a}$, L. Rendón ${ }^{a}$ and E. Alzate ${ }^{a}$ \\ ${ }^{a}$ Centro de Estudios y de Investigación en Biotecnología - CIBIOT, Facultad de Ingeniería Química, Escuela de \\ Ingenierías, Universidad Pontificia Bolivariana - UPB, Circular 1 No. 70-01, Postal Code 050031, Medellín, Colombia \\ *e-mail: margarita.ramirez@upb.edu.co
}

Received: September 16, 2016 - Accepted: February 1, 2017 - Distributed: October 31, 2018

(With 4 figures)

\begin{abstract}
In this work it was carried out the bioremediation of water containing chlorides with native microalgae (MCA) provided by the Centre for study and research in biotechnology (CIBIOT) at Universidad Pontificia Bolivariana. Microalgae presented an adaptation to the water and so the conditions evaluated reaching a production of $\mathrm{CO}_{2}$ in $\mathrm{mg}$ $\mathrm{L}^{-1}$ of 53.0, 26.6, 56.0, 16.0 and 30.0 and chloride removal efficiencies of 16.37, 26.03, 40.04, 25.96 and $20.25 \%$ for microalgae1, microalgae 2 , microalgae 3 , microalgae4 and microalgae 5 respectively. Water bioremediation process was carried out with content of chlorides in fed batch system with an initial concentration of chlorides of $20585 \mathrm{mg}$ $\mathrm{L}^{-1}$ every 2 days. The Manipulated variables were: the flow of MCA3 (10\% inoculum) for test one; NPK flow for test two, and flow of flow of MCA3 $+0.5 \mathrm{~g} \mathrm{~L}^{-1} \mathrm{NPK}$. Chloride removal efficiencies were $66.88 \%, 63.41 \%$ and $66.98 \%$ for test one, two and three respectively, for a total bioprocess time of 55 days.
\end{abstract}

Keywords: chlorides in water, bioremediation, native algae, paper industry, feed batch.

\section{Potencial de microalga na biorremediação da água com conteúdo de cloretos}

\section{Resumo}

Neste trabalho avaliou-se a biorremediação da água com conteúdos de cloretos utilizando microalgas nativas (MCA) fornecidas pelo Centro de Estudos e Pesquisas em Biotecnologia (CIBIOT) da Universidad Pontifícia Bolivariana. As microalgas empregadas apresentaram uma adaptação ao meio de cultura e as condições operacionais avaliadas atingindo uma produção de $\mathrm{CO} 2 \mathrm{em} \mathrm{mg} \mathrm{L}^{-1}$ de $53,0,26,6,56,0,16,0$ e 30,0 e eficiências de remoção de cloretos de 16,37, 26,03, 40,04, 25,96 e 20,25\% para MCA1, MCA2, MCA3, MCA4 e MCA5 respectivamente. A biorremediação da água com conteúdos de cloretos foi realizada em modo batelada alimentada (Feed Batch) com uma concentração inicial de cloretos de $20585 \mathrm{mg} \mathrm{L}^{-1}$. A alimentação foi realizada a cada 2 dias. A variável manipulada foi: ensaio um, uma vazão de MCA3 ( $10 \%$ de inoculo); ensaio dois, uma vazão de NPK e ensaio três, uma vazão de MCA3+0,5 g L-1 NPK. As eficiências de remoção foram $66,88 \%, 63,41 \%$ e $66,98 \%$ para os ensaios um, dois e três, respectivamente num tempo do bioprocesso total de 55 dias.

Palavras-chave: cloretos na água, biorremediação, algas nativas, industria de papel, batelada alimentada.

\section{Introduction}

The industrial operations from manufactures generates toxic substances that are dumped in riverbed receivers, emitted to the atmosphere and deposited in soils where its transformation as a point of arrival has ecosystems, generating effects, both for wildlife and for man (Ávila et al., 2015; Escapa and García, 2013; Figueiredo-Sganderla et al., 2010; Ramírez et al., 2012; Souza et al., 2016; Steffens et al., 2015). The pulp and paper industry is the sixth most polluting after oil, cement, leather, textile and steel industries (Cassanego and Droste, 2017; Pereira et al., 2009; Muthukumar and Vediyappan, 2010).
The processing of pulp and bleaching paper produces organic chlorinated toxic compounds, including dioxins and furans, compounds that attack the muscle-skeletal, respiratory, reproductive, and central nervous system, the skin, the liver and kidneys. These compounds are considered to be human carcinogens (Pereira et al., 2009; Muthukumar and Vediyappan, 2010; Cheng et al., 2013; Tian et al., 2013).

Legislative models, environmental sensitivity and the increased concern about the water supply are tending to the treatability studies of the poured water from the chemical processes industries (Benvenuti et al., 2015; 
Ramos et al., 2010). The common physicochemical treatments used are complex and/or present energy consumption between the $60-80 \%$ of the total purifying process (Lam and Lee, 2012).

For the treatment of waste water especially those coming from the bleaching of paper production process applied different techniques such as freeze, adsorption and purification with chemical processing, distillation and reverse osmosis, the last two being more employees to be more efficient (Dore, 2005; Hsu and Jou, 2013).

As alternative methods biological processes are commonly used, in these methods contaminants are degraded in a further phase of the carbon cycle, transforming organic compounds to methane, $\mathrm{CO}_{2}$ and other inorganic products (Chellappa et al., 2008; Ferão-Filho et al., 2005; Song et al., 2014).

Studies suggest that bacteria such as Pseudomonas sp., Ancylobacter aquaticus, Methylobacterium sp can reduce chlorinated compounds. The results of these studies show inefficiencies to remove significant amounts of these compounds. It was found that waste water containing calcium and magnesium chloride should be diluted to prevent the death of the bacteria (Escapa and García, 2013).

Another alternative method in biological processes are culture of photosynthetic microorganisms including algae; it has been shown that halophilic microorganisms have a high capacity of bioremediation, since they can be used as a catalyst in various processes where extreme conditions are required to efficiently repair a contaminated environment (Castillo and Barragán, 2011; Escapa and García, 2013; Pereira et al., 2009).

The cultivation of microalgae offers advantages for the waste water treatment, since they provide a tertiary biotreatment along with the production of biomass, which can be used for several purposes (Rendón et al., 2015). Algae in the process of bioremediation of water use their photosynthetic capacity, allowing them to convert solar energy into biomass, and then incorporate nutrients such as nitrogen and phosphorus which are responsible for eutrophication (Abdel-Raouf et al., 2012; Sánchez et al., 2013). Processes that use micro-algae and cyanobacteria are mainly focused on the removal of nutrients and heavy metals in waste water (Escapa and García, 2013).

The processes of bioremediation through the cultivation of microalgae are used since the end of the 1950s. Thenceforth, microalgae have been gaining attention in the treatment of urban industrial and agricultural wastewater employing Chlorella sp., Scenedesmus sp. and Muriellopsis sp. In a study carried out by Wang et al. (2010) they showed the ability of microalgae on bacteria and fungi to remove metals such as iron, aluminum, manganese, magnesium and zinc of four different types of wastewater with removal percentages between $56 \%$ and $100 \%$ (Fimbres-Olivarría et al., 2010; Wang et al., 2010; Li et al., 2011; Chi et al., 2011; Mulbry et al., 2009; Chinnasamy et al., 2010; Markou and Georgakakis, 2011).

In this study, the bioremediation of water containing chlorides was performed by using different species of microalgae in batch and fed batch processes.

\section{Materials and Methods}

\subsection{Microalgae}

Five microalgae strains were employed in this study. They were supplied by the Centro de Estudios y de Investigación en Biotecnología (CIBIOT) at Universidad Pontificia Bolivariana.

These species were selected: MCA1, MCA2, MCA3, MCA4 and MCA5, since they keep alive at pH 4-9.5, values that are found in chlorinated waters (Abdel-Raouf et al., 2012).

Microalgae were preserved in clarified water supplemented with chloride and salts (MCLS): $27 \mathrm{~g} \mathrm{~L}^{-1} \mathrm{NaCl}, 3.2 \mathrm{~g} \mathrm{~L}^{-1} \mathrm{MgCl}_{2}$, $1.6 \mathrm{~g} \mathrm{~L}^{-1} \mathrm{MgSO}_{4}, 1.3 \mathrm{~g} \mathrm{~L}^{-1} \mathrm{CaSO}_{4}, 0.8 \mathrm{~g} \mathrm{~L}^{-1} \mathrm{~K}_{2} \mathrm{SO}_{4}$, $0.5 \mathrm{~g} \mathrm{~L}^{-1} \mathrm{KCl}, 0.1 \mathrm{~g} \mathrm{~L}^{-1} \mathrm{CaCO}_{3}$. Additionally, the medium was supplemented with $0.5 \mathrm{~g} \mathrm{~L}^{-1}$ of NPK in order to maintain a viable microalgae culture. Microalgae were incubated every 15 days using the same medium composition.

\subsection{Microalgal growth kinetics}

In order to obtain the growth kinetics of microalgae for each specie, indirect growth by technical respirometric techniques was employed through the measurement of $\mathrm{CO}_{2}$ produced by using an OXITOP Box WTW system. $100 \mathrm{~mL}$ of medium were prepared and inoculated with $20 \%$ of each microalgae with an initial concentration of chlorides of $20,585.00 \mathrm{mg} \mathrm{L}^{-1}$ and a $\mathrm{pH}$ of 7.86 during 7 days.

\subsection{Bioremediation}

The bioremediation process of water containing chloride was performed with microalgae MCA3 (inoculum 20\%) in a culture medium MCLS supplemented with $0.5 \mathrm{~g} \mathrm{~L}^{-1} \mathrm{NPK}$ in $3 \mathrm{~L}$ bioreactors by using a working volume of $2 \mathrm{~L}$, a concentration of chlorides of 20,585.00 $\mathrm{mg} \mathrm{L}^{-1}, \mathrm{pH} 8.0$, temperature $25^{\circ} \mathrm{C}$, air flow of $0.87 \mathrm{~L} \mathrm{~min}^{-1}$ and light intensity of 1,680.00 lumens (fluorescent lamp, chromatic temperature of $6,400.00 \mathrm{~K}$ ) for 55 days.

Three bioremediation processes were carried out in a fed batch mode. The feed was set every 2 days. The manipulated variable were: for trial one, MCA3 flow (10\% inoculum); for trial two, flow of NPK (E2) and for trial three the flow of MCA3+ NPK (E3).

$10 \mathrm{~mL}$ daily sample were taken to establish the microalgae growth and determine the concentration of chlorides.

\subsection{Characterization}

The samples were characterized every day through quantification of total chlorides by potentiometric qualification (pHmetro Mettler Toledo, SevenEasy) using $\mathrm{AgNO}_{3}$ as titration reagent (Metrohm, 2010) and the growth of algae was determined by dry weight (Fimbres-Olivarría et al., 2010).

\section{Results and Discussion}

In this research, microalgae was selected for bioremediation of water containing chlorides due to their capability of transforming inorganic matter into organic using the Sun's energy during the process of photosynthesis (Rendón et al., 2015). 
Figure 1 shows the results of growth kinetics for each microalgae evaluated.

The results in Figure 1 show the adaptation of microalgae to the medium and evaluated conditions. Microalgae presented an exponential growth, reaching a production of $\mathrm{CO}_{2}$ in ppm $\left(\mathrm{mg} \mathrm{L}^{-1}\right)$ of 53.0, 26.6, 56.0, 16.0 and 30.0 for MCA1, MCA2, MCA3, MCA4 and MCA5 respectively without presenting latent phase, except for MCA2 which showed a day at this phase. The affinity of microalgae with the MCLS medium in descending order was 28.8, 19.3, 11.3, 6.4 and 2.0 for MCA3, MCA1, MCA2, MCA5, and MCA4 respectively.

The Microalgae despite not having organic substrates in the medium were able to grow and maintain, due to they are halophilic microorganisms capable of reproduce and perform their metabolic functions in an effective way in the presence of high concentrations of salts (El-Sayed et al., 2010).

In addition, microalgae as halophilic microorganisms have strategies that enable them to face the osmotic stress, maintaining high intracellular concentrations of salt and synthesizing compatible solutes that allow them to balance their osmotic pressure (Castillo and Barragán, 2011; Li et al., 2011).

The change of $\mathrm{pH}$ during the trials was not significant during the 7 days performing the bioprocess; the initial value was 8.0 units and it changed to $8.32,8.3,8.03,8.5$ and 8.73 as well as efficiencies of removal of chlorides were $16.37,26.03,40.04,25.96$ and $20.25 \%$ for MCA1, MCA2, MCA3, MCA4 and MCA5 respectively.

MCA3 was selected for the process of bioremediation of waters with content of chlorides due to its $\mathrm{pH}$ variation of 0.03 units, a $40 \%$ removal efficiency and an affinity of 28.8 .

\subsection{Bioremediation}

According to the results of the growth kinetics of MCA3, in which a bioremediation of $40 \%$ efficiency was achieved, it was decided to work in fed batch mode in order to achieve an increase in process efficiency. Studies of degradation of crudes show the efficiency of the process by using fed batch and reaching values above $87 \%$ (Liu and Liu, 2011). In recent years, engineering methods were applied to optimize the biotechnical production processes focusing on dynamic optimization or fed batch reactors by setting the feeding substrate rate as the manipulated variable (Rocha et al., 2014).

Results for those three Fed Batch bioremediations are shown in Figures 2-4.

Figures 2-4 show a decreasing trend in the concentration of chlorides due to possibly the capacity of microalgae to remove chlorine ions. In addition, microalgae produce lipids and polyols, indicating the possible role of these compounds as osmoregulators in algae, as a substance which in the concentration that is responding positively to the concentration of extracellular solute, adversely to the water activity $(w a)$, and thus maintains approximately equal between the internal and external of the $w a$ and therefore minimizes the osmotic stress and dehydration

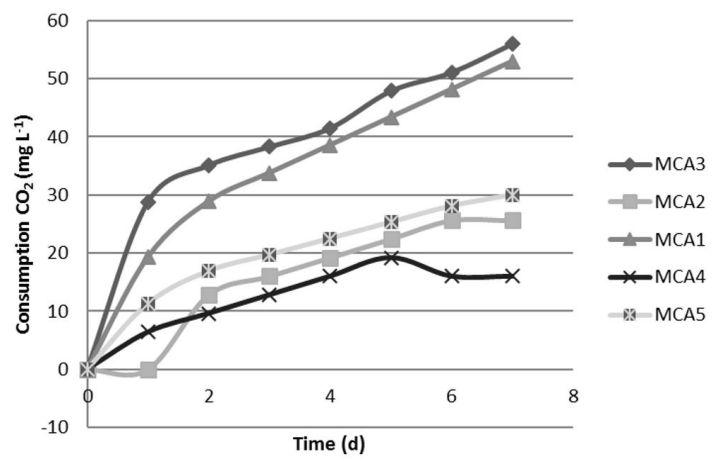

Figure 1. Growth kinetics of algae on clarified water by using MCLS medium.

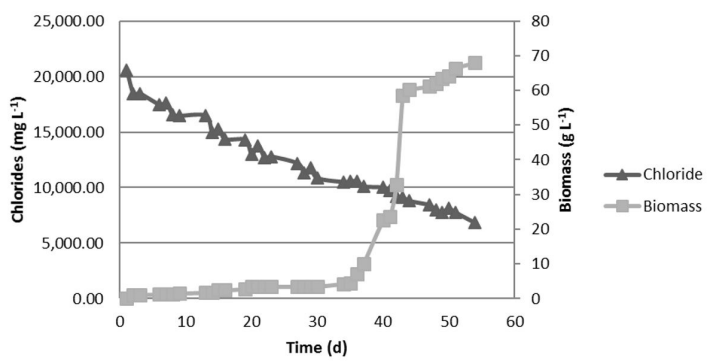

Figure 2. Relationship between growth of the microalgae and the concentration of chlorides during the process of bioremediation (manipulated Variable: MCA3) (E1).

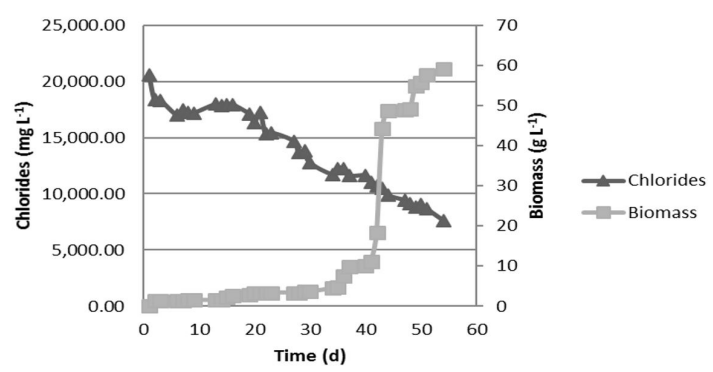

Figure 3. Relationship between growth of the microalgae and the concentration of chlorides during the process of bioremediation (manipulated Variable: Supplement to the substrate with $0.5 \mathrm{~g} \mathrm{~L}-1 \mathrm{NPK}$ ) (E2).

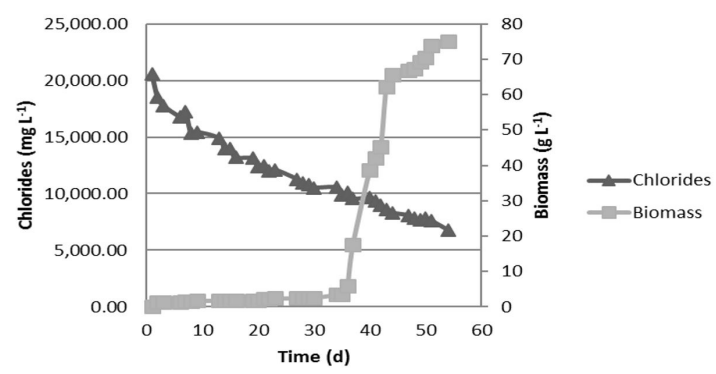

Figure 4. Relationship between growth of the microalga and the concentration of chlorides during the process of bioremediation (manipulated Variable: Supplement to the substrate with microalgae NPK) (E3). 
which the cell is subject. Its function is to make permeable the microalga wall (El-Sayed et al., 2010; Castillo and Barragán, 2011; Li et al., 2011).

Microalgae growth reached at 55 days was $75.2 \mathrm{~g} \mathrm{~L}^{-1}$, $68 \mathrm{~g} \mathrm{~L}^{-1}$ and $58.9 \mathrm{~g} \mathrm{~L}^{-1}$ when variable such as microorganism (MCA3) (E1), substrate supplement $0.5 \mathrm{~g} \mathrm{~L}^{-1} \mathrm{NPK}$ (E2) and NPK MCA3 (E3) were manipulated respectively.

Chloride removal efficiencies were $66.88 \%, 63.41 \%$ and $66.98 \%$ for trials E1, E2 and E3, respectively. Both, trial E2 and E3 were fed by using microalgae, where the second one was supplemented with NPK because it has been shown that it can increase the solubility of some nutrients and lower $\mathrm{pH}$ values, additionally, NPK acts as an additional carbon source creating a directly proportional effect on the biomass production (El-Sayed et al., 2010).

In this study, the manipulated variable of feed which showed a $67 \%$ efficiency was the mixture of the complement of the substrate $0.5 \mathrm{~g} \mathrm{~L}^{-1} \mathrm{NPK}$ and inoculum of the $10 \%$ of MCA3 simultaneously, since the goal was to lower the concentration of chlorides. The results show that the process feed must be non-sterile and showing relevance when adding Microalgae supplemented with NPK.

In previous studies, it was reported the reduction of chlorides in water by using microalgae Scenedesmus sp., reaching a salt removal percentage of $25 \%$ (El-Sayed et al., 2010) in this study, salt removal percentage surpassed those results in $41.98 \%$.

\section{Conclusions}

From evaluated microalgae, MCA3 was selected in the bioremediation process after show the best kinetics of indirect growth of $56 \mathrm{mg} \mathrm{L}^{-1}$ of $\mathrm{CO}_{2}$ and a variation of $0.03 \mathrm{pH}$ units, a $40 \%$ removal efficiency and a 28.8 affinity units.

In the process of bioremediation of water containing chlorides in a batch fed system with MCA3 microalgae using $0.5 \mathrm{~g} \mathrm{~L}^{-1} \mathrm{NPK}$ as supplement, in bioreactors of $3 \mathrm{~L}$ with a working volume of $2 \mathrm{~L}$, an initial concentration of chlorides of 20,585.00 mg L-1, $\mathrm{pH}$ of 8.0, temperature $25{ }^{\circ} \mathrm{C}$, air flow of $0.87 \mathrm{~L} \mathrm{~min}^{-1}$ and light intensity of 1,680.00 lumens (fluorescent lamp with chromatic temperature of $6,400.00 \mathrm{~K}$ ) during 55 days it was found a $66.98 \%$ removal efficiency for chloride ions when the manipulated variable was the feed flow of MCA3+NPK.

\section{Acknowledgements}

Authors wish to express their gratitude to COLCIENCIAS by the economic support during the "young researchers" program, and also to Centro de Investigación para el desarrollo y la Innovación - CIDI at University Pontificia Bolivariana for its program of research trainees, who made possible the development of this study.

\section{References}

ABDEL-RAOUF, N., AL-HOMAIDAN, A. and IBRAHEEM, I.B.M., 2012. Microalgae and wastewater treatment. Saudi Journal of Biological Sciences, vol. 19, no. 3, pp. 257-275. PMid:24936135. http://dx.doi.org/10.1016/j.sjbs.2012.04.005.

ÁVILA, C.L., BIANCHIN, L. and ILLI, J., 2015. Preliminary assessment of pseudo-total and bioavailable metals in depth in the sediment of Luíz Rau stream in Novo Hamburgo (RS). Brazilian Journal of Biology $=$ Revista Brasileira de Biologia, vol. 75, no. 4, suppl. 2, pp. 30-36. PMid:26628225. http://dx.doi. org/10.1590/1519-6984.00213suppl.

BENVENUTi, T., RODRIGUES, M., ARENZON, A., BERNARDES, A. and ZOPPAS-FERREIRA, J., 2015. Toxicity effects of nickel electroplating effluents treated by photoelectrooxidation in the industries of the Sinos River Basin. Brazilian Journal of Biology = Revista Brasileira de Biologia, vol. 75, no. 2, suppl., pp. 17-24. PMid:26270209. http://dx.doi. org/10.1590/1519-6984.1113.

CASSAnEGO, M.B. and Droste, A., 2017. Assessing the spatial pattern of a river water quality in southern Brazil by multivariate analysis of biological and chemical indicators. Brazilian Journal of Biology = Revista Brasileira de Biologia, vol. 77, no. 1, pp. 118-126. PMid:27383001. http://dx.doi. org/10.1590/1519-6984.11215.

CASTILlO, L. and BARRAGÁN, B., 2011. Aplicaciones Biotecnológicas de microorganismos halófilos. Revista Sistemas Ambientales, vol. 4, no. 2, pp. 45-54.

CHELlAPPA, N.T., BORBA, J.M. and ROCHA, O., 2008. Phytoplankton community and physical-chemical characteristics of water in the public reservoir of Cruzeta, RN, Brazil. Brazilian Journal of Biology $=$ Revista Brasileira de Biologia, vol. 68, no. 3, pp. 477-494. PMid:18833468. http://dx.doi.org/10.1590/ S1519-69842008000300004.

CHENG, C., PENG, R., HAIle, S., CHEN, Y., CHEN, M., JHANG, D. and FAN, H., 2013. Nutrient recovery from nitrocellulose manufacturing wastewater. Sustainable Environment Research, vol. 23, no. 1, pp. 33-39.

CHI, Z., ZHENG, Y., JIANG, A. and CHEN, S., 2011. Lipid production by culturing oleaginous yeast and algae with food waste and municipal wastewater in an integrated process. Applied Biochemistry and Biotechnology, vol. 165, no. 2, pp. 442-453. PMid:21567213. http://dx.doi.org/10.1007/s12010-011-9263-6.

CHINNASAMY, S., BHATNAGAR, A., HUNT, R. and DAS, K.C., 2010. Microalgae cultivation in a wastewater dominated by carpet mill effluents for biofuel applications. Bioresource Technology, vol. 101, no. 9, pp. 3097-3105. PMid:20053551. http://dx.doi.org/10.1016/j.biortech.2009.12.026.

DORE, M., 2005. Forecasting the economic costs of desalination technology. Journal of Water Process Engineering, vol. 172, no. 3, pp. 207-214.

EL-SAYED, A., EL-FOULY, M. and EL-NOUR, E., 2010. Immobilized Microalga Scenedesmus sp. for biological desalination of red sea water: I. effect on growth. Nature and Science, vol. 8, no. 9, pp. 69-76.

ESCAPA, C. and GARCÍA, A., 2013. Eliminación de nutrientes en aguas residuales y biofijación de $\mathrm{CO}_{2}$ mediante el cultivo de microalgas. In: Science Society of Galicia, 2 November 2013, Galicia, España. Galicia: Sociedad de Ciencias de Galicia, Pontevedra, pp. 63-76.

FERÃO-FILHO, A.S., ARCIFA, M.S. and FILETO, C., 2005. Influence of seston quantity and quality on growth of tropical cladocerans. Brazilian Journal of Biology $=$ Revista Brasileira 
de Biologia, vol. 65, no. 1, pp. 77-89. PMid:16025906. http:// dx.doi.org/10.1590/S1519-69842005000100011.

FIGUEIREDO-SGANDERLA, J.A., PRODANOV, C. and DAROIT, D., 2010. Impacts of the globalized economy on the environment: the tanning industry in the Vale do Rio dos Sinos. Brazilian Journal of Biology $=$ Revista Brasileira de Biologia, vol. 70, no. 4, suppl., pp. 1231-1243. PMid:21225165. http:// dx.doi.org/10.1590/S1519-69842010000600013.

FIMBRES-OLIVARRÍA, D., MERCADO-CASTILLO, L.R., MURGUÍA-LÓPEZ, Á. and LÓPEZ-ELÍAS, J.A., 2010. Crecimiento y biomasa de Dunaliella sp. cultivada en medios limitantes en nitrógeno. BIOtecnia., vol. 12, no. 3, pp. 58-66. http://dx.doi.org/10.18633/bt.v12i3.104.

HSU, C.-K. and JOU, C.-J.G., 2013. Catalytic degradation of chlorobenzene in aqueous solution with microwave and waste metals. Sustainable Environment Research., vol. 23, no. 1, pp. 49-52.

LAM, M.K. and LEE, K., 2012. Microalgae biofuels: a critical review of issues, problems and the way forward. Biotechnology Advances, vol. 30, no. 3, pp. 673-690. PMid:22166620. http:// dx.doi.org/10.1016/j.biotechadv.2011.11.008.

LI, Y., CHEN, Y.-F., CHEN, P., MIN, M., ZHOU, W., MARTINEZ, B., ZHU, J. and RUAN, R., 2011. Characterization of a microalga Chlorella sp. well adapted to highly concentrated municipal wastewater for nutrient removal and biodiesel production. Bioresource Technology, vol. 102, no. 8, pp. 5138-5144. PMid:21353532. http://dx.doi.org/10.1016/j.biortech.2011.01.091.

LIU, C.-W. and LIU, H.-S., 2011. Rhodococcus erythropolis strain NTU-1 efficiently degrades and traps diesel and crude oil in batch and fed-batch bioreactors. Process Biochemistry, vol. 46, no. 1, pp. 202-209. http://dx.doi.org/10.1016/j.procbio.2010.08.008.

MARKOU, G. and GEORGAKAKIS, D., 2011. Cultivation of filamentous cyanobacteria (blue green algae) in agro-industrial wastes and wastewaters: a review. Applied Energy, vol. 88, no. 10, pp. 3389-3401. http://dx.doi.org/10.1016/j.apenergy.2010.12.042.

METROHM, 2010 [viewed 16 September 2016]. Metrohm Chloride titrations with potentiometric indication: protocol [online]. German. Application Bulletin, 130/3. Available from: http://www.metrohm.com/com/Search/index.html?identifier=AB$130 \&$ language $=$ en

MULBRY, W., KONDRAD, S., BUYER, J. and LUTHRIA, D., 2009. Optimization of an oil extraction process for algae from the treatment of manure effluent. Journal of the American Oil Chemists'Society, vol. 86, no. 9, pp. 909-915. http://dx.doi. org/10.1007/s11746-009-1432-1.

MUTHUKUMAR, T. and VEDIYAPPAN, S., 2010. Comparison of arbuscular mycorrhizal and dark septate endophyte fungal associations in soils irrigated with pulp and paper mill efuent and well-water European. Eur J Soil Biology and Biochemistry, vol. 46, no. 2, pp. 157-167. http://dx.doi.org/10.1016/j.ejsobi.2009.12.003.

PEREIRA, R., ANTUNES, S.C., GONÇALVES, A.M.M., MARQUES, S.M., GONÇALVES, F., FERREIRA, F., FREITAS, A.C., ROCHA-SANTOS, T.A.P., DINIZ, M.S., CASTRO, L., PERES, I. and DUARTE, A.C., 2009. The effectiveness of a biological treatment with Rhizopus oryzae and of a photo-Fenton oxidation in the mitigation of toxicity of a bleached kraft pulp mill effluent. Water Research, vol. 43, no. 9, pp. 2471-2480. PMid:19345976. http://dx.doi.org/10.1016/j.watres.2009.03.013.

RAMIREZ, M., PEREIRA, M., FERREIRA, S., VASCO, O. and OCAMPO, C., 2012. Packed bed redistribution system for $\mathrm{Cr}$ (III) and Cr (VI) biosorption by Saccharomyces cerevisiae. Journal of the Taiwan Institute of Chemical Engineers, vol. 43, no. 3, pp. 428-432. http://dx.doi.org/10.1016/j.jtice.2011.12.002.

RAMOS, R., VINATEA, L., SANTOS, J. and COSTA, R., 2010. Tratamiento de efluentes del cultivo de Litopenaeus vannamei mediante procesos de sedimentación, filtración y absorción. Latin American Journal of Aquatic Research, vol. 38, no. 2, pp. 188-200. http://dx.doi.org/10.3856/vol38-issue2-fulltext-3.

RENDÓN, L., RAMÍREZ, M. and VÉLEZ, Y., 2015 [viewed 16 September 2016]. Microalgas para la industria alimenticia [online]. 1st ed. Medellín: Universidad Pontifica Bolivariana. Available from: http://repository.upb.edu.co:8080/jspui/ handle/123456789/2306

ROCHA, M., MENDES, R., ROCHA, O., ROCHA, I. and FERREIRA, E., 2014. Optimization of fed-batch fermentation processes with bio-inspired algorithms. Expert Systems with Applications, vol. 41, no. 5, pp. 2186-2195. http://dx.doi. org/10.1016/j.eswa.2013.09.017.

SÁNCHEZ, A., MIRANDA, A., LÓPEZ, J., MARTÍNEZ, L., TEJEDA, A. and MÁRQUEZ, E., 2013. Efecto del fotoperiodo y la razón camarón:macroalga en la remoción de nitrógeno amoniacal total por Gracilaria vermiculophylla, en cultivo con Litopenaeus vannamei, sin recambio de agua. Latin American Journal of Aquatic Research, vol. 41, no. 5, pp. 888-897.

SONG, X., HONG, E. and SEAGREN, E., 2014. Laboratoryscale in situ bioremediation in heterogeneous porous media: biokinetics-limited scenario. Journal of Contaminant Hydrology, vol. 158, pp. 78-92. PMid:24508684. http://dx.doi.org/10.1016/j. jconhyd.2014.01.001.

SOUZA, A.M., SALVIANO, A., MELO, J., FELIX, W., BELÉM, C. and RAMOS, P., 2016. Seasonal study of concentration of heavy metals in waters from lower São Francisco River basin, Brazil. Brazilian Journal of Biology $=$ Revista Brasileira de Biologia, vol. 76, no. 4, pp. 967-974. PMid:27166571. http:// dx.doi.org/10.1590/1519-6984.05215.

STEFFENS, C., KLAUCK, C.R., BENVENUTI, T., SILVA, L.B. and RODRIGUES, M.A.S., 2015. Water quality assessment of the Sinos River - RS, Brazil. Brazilian Journal of Biology = Revista Brasileira de Biologia, vol. 75, no. 4, suppl. 2, pp. 62-67. PMid:26628228. http://dx.doi.org/10.1590/1519-6984.01613suppl.

TIAN, C., LIU, R., LIU, H. and QU, J., 2013. Disinfection by-products formation and precursors transformation during chlorination and chloramination of highly-polluted source water: significance of ammonia. Water Research, vol. 47, no. 15, pp. 5901-5910. PMid:23911224.

WANG, L., MIN, M., LI, Y., CHEN, P., CHEN, Y., LIU, Y., WANG, Y. and RUAN, R., 2010. Cultivation of green algae Chlorella $s p$. in different wastewaters from municipal wastewater treatment plant. Applied Biochemistry and Biotechnology, vol. 162, no. 4, pp. 1174-1186. PMid:19937154. http://dx.doi.org/10.1007/ s12010-009-8866-7. 